\title{
Rhizobium leguminosarum nodulation gene (nod) expression is lowered by an allele- specific mutation in the dicarboxylate transport gene dctB
}

\author{
Annoula Mavridou, ${ }^{1} \dagger$ Marie-Anne Barny, ${ }^{1} \ddagger$ Philip Poole, ${ }^{2}$ Kitty Plaskitt, ${ }^{1}$ \\ Andrea E. Davies, ${ }^{1}$ Andrew W. B. Johnston ${ }^{3}$ and J. Allan Downie ${ }^{1}$
}

Author for correspondence: J. Allan Downie. Tel: +44 1603 52571. Fax: +44 160356844.

1 John Innes Centre, Colney Lane, Norwich NR4 7UH, UK

2 Department of

Microbiology, University of Reading, Reading RG6 2AJ, UK

3 School of Biological Sciences, University of East Anglia, Norwich NR4 7TJ, UK

To identify host genes that might influence nod (nodulation) gene expression in Rhizobium leguminosarum, a nodC-phoA reporter plasmid (carrying nodD) was introduced into a chemically mutagenized population of a $R$. leguminosarum strain lacking a symbiotic plasmid. The transconjugants were screened for expression of alkaline phosphatase (PhoA) on plates containing hesperetin, an inducer of nod genes, and a mutant with reduced expression was identified. When the nodC-phoA plasmid was cured from the mutant and the symbiotic plasmid pRL1JI introduced, the mutant formed nodules, but symbiotic nitrogen fixation was less than $\mathbf{2 0} \%$ of normal. When the nodC-phoA allele was introduced on PRL1JI a low level of nod gene induction was found. The reduced nodC expression appeared to be caused by a decrease in expression of the regulatory gene nodD, since expression of a nodD-lacz fusion was also lower in the mutant than in the control. These mutant phenotypes and the low nitrogen fixation were complemented with a plasmid (pIJ1848) from a $R$. leguminosarum cosmid library. DNA hybridization confirmed that pIJ1848 was not from the symbiotic plasmid and showed that a DNA insertion was present in the mutant. The complementing region of pIJ1848 was defined by transposon mutagenesis; DNA sequencing revealed that it carried the dicarboxylic acid transport (dct) genes. However, the mutant grew well with succinate as sole C-source. Genetic analysis revealed that the mutant appeared to contain IS50 in the regulatory gene dctB and that this mutation caused the reduction in nod gene expression. The effect was allelespecific since other mutations in dctB did not influence nod gene expression. Surprisingly, the mutant had a constitutive high level of succinate transport, indicating that the mutation caused unregulated expression of $\operatorname{dct} A$ the structural gene for dicarboxylic acid transport. This in some way appears to have lowered the expression of nodD, indicating that the nodD promoter may be influenced by the metabolic status of the cells or by expression of dctD in the absence of dctB.

Keywords: Rbizobium leguminosarum, nod, gene regulation, succinate, symbiotic nitrogen fixation

\section{INTRODUCTION}

The nodulation (nod) genes of Rhizobium leguminosarum biovar viciae are involved in the synthesis of signals required for the formation of nitrogen-fixing nodules on

† Present address: Agiou loannou 26, Thessaloniki 55132, Greece. $\ddagger$ Present address: INRA, rue George Morel, Beaucouze 49070, France. legumes such as Pisum sativum (pea) and the vetch Vicia birsuta (Göttfert, 1993). In one well-characterized strain of R. l. viciae, 13 nod genes have been identified (Downie, 1991). Twelve of these, in four operons (nod $A B C I J$, $\operatorname{nodFEL}, \operatorname{nod} M N T$ and nod $O$ ), are under the regulatory

Abbreviations: PhoA, alkaline phosphatase; X-P, 5-bromo-4-chloro-3indolyl phosphate. 
control of NodD (Schlaman et al., 1992), a DNA-binding protein (Hong et al., 1987) encoded by nodD in a fifth operon.

Under normal laboratory growth conditions, nodD is expressed constitutively (Rossen et al., 1985) but the other nod gene operons are not induced. Specific flavonoid molecules such as naringenin, hesperetin and eriodictiol, normally present in the rhizosphere of legumes, strongly induce nod gene expression (Firmin et al., 1986; Recourt $e t$ al., 1991), and this induction is nodD-dependent (Rossen et al., 1985; Spaink et al., 1987). Circumstantial evidence indicates that there is a direct interaction between the flavonoids and NodD (Burn et al., 1987; Spaink et al., 1989), although no direct binding has been shown.

Several other factors can influence nod gene expression. It appears that the level of flavonoid-dependent induction is growth-phase dependent (Djordjevic et al., 1987). In the closely related species $\mathrm{R}$. meliloti, $\mathrm{NH}_{4}^{+}$ions can repress nod gene induction (Dusha \& Kondorosi, 1993), although this is not the case with R. l. viciae (Baev et al., 1992). A repressor of nod gene expression is found in some strains of R. meliloti (Kondorosi et al., 1989), but a similar repressor has not been found in R. l. viciae. It is also evident that nod gene expression ceases when rhizobia become nitrogen-fixing bacteroids within plant cells; this is thought to be due to specific repression of nod gene expression (Schlaman et al., 1991).

We took a genetic approach to identify factors that might influence flavonoid-dependent nod gene induction in R. $l$. viciae. A mutation that caused lowered nod gene expression was identified and shown to have resulted from a mutation in the $d c t B$ (dicarboxylate) gene.

\section{METHODS}

Bacterial strains and growth. Strains and plasmids are described in Table 1 and/or the text. Rhizobial strains were grown in TY complete medium (Beringer, 1974), or Y minimal medium supplemented with $10 \mathrm{mM}$ sodium glutamate, sodium aspartate or $\mathrm{NH}_{4} \mathrm{Cl}$ as $\mathrm{N}$-source, and $10 \mathrm{mM}$ succinate, mannitol or glucose as a C-source. Escherichia coli was grown in LB medium (Maniatis et al., 1982). Where appropriate, antibiotics were added as follows : streptomycin, $400 \mu \mathrm{g} \mathrm{m}^{-1}$; kanamycin, $20 \mu \mathrm{g}$ $\mathrm{ml}^{-1}$; tetracycline, $5 \mu \mathrm{g} \mathrm{m}^{-1}$; gentamicin, $5 \mu \mathrm{g} \mathrm{ml}^{-1}$; carbenicillin, $10 \mu \mathrm{g} \mathrm{ml}^{-1}$. Bacterial growth was monitored at $600 \mathrm{~nm}$ using a Bausch \& Lomb Spectronic 20 spectrophotometer. Levels of induction of nod gene fusions were assessed on $\mathrm{Y}$ plates containing $1 \mu \mathrm{M}$ hesperetin and $40 \mu \mathrm{g} \mathrm{ml}^{-1}$ of either X-Gal or 5-bromo-4-chloro-3-indolyl phosphate (X-P) for $\beta$-galactosidase or alkaline phosphatase (PhoA) fusions, respectively. nod gene expression was assayed using rhizobia grown in $\mathrm{Y}$ medium containing mannitol and $\mathrm{NH}_{4} \mathrm{Cl}$ and assayed for $\beta$-galactosidase (Rossen et al., 1985) or alkaline phosphatase activities (Cubo et al., 1992).

For succinate uptake, cells were grown to mid-exponential phase (about $5 \times 10^{8}$ cells $\mathrm{ml}^{-1}$ ) in Y medium containing glucose and $\mathrm{NH}_{4} \mathrm{Cl}$ or sodium aspartate. The cells were harvested by centrifugation, then washed and resuspended in minimal medium lacking a $\mathrm{C}$ - or $\mathrm{N}$-source. Transport was measured as described by Poole et al. (1985) using $18.5 \mathrm{kBq}$ of $[2,3$ $\left.{ }^{14} \mathrm{C}\right]$ succinate $\left(4 \cdot 0 \mathrm{GBq} \mathrm{mmol}^{-1}\right)$ at a total substrate concentration of $25 \mu \mathrm{M}$.
Genetic manipulations. Plasmids were transferred by conjugation as described by Johnston et al. (1978). Transfer of plasmids from $E$. coli to $R$. leguminosarum involved triparental matings using the helper plasmid pRK2013 (Figurski \& Helinski, 1979). Mutagenesis of $\mathrm{pIJ1848}$ with Tn5-lacZ was done by transforming $E$. coli A118 with pIJ1848 and then selecting mutated derivatives following conjugation into $R$. leguminosarum A150, essentially as described by Surin et al. (1990). Transductions were done using the $R$. leguminosarum phage RL38 as described by Buchanan-Wollaston (1979).

Mutagenesis with NTG was done by placing a few crystals onto the centre of a TY plate that had been spread with a lawn of strain 8401 . After $4 \mathrm{~d}$ at $28^{\circ} \mathrm{C}$, slowly growing cells from the zone of inhibited growth were scraped off the agar and resuspended in TY medium. After $16 \mathrm{~h}$ growth at $28^{\circ} \mathrm{C}$, pIJ1687 was transferred into the population by a triparental mating. Transconjugants were selected on $\mathrm{Y}$ medium using streptomycin and kanamycin with hesperitin plus X-P to identify mutants with altered nod gene expression.

The cosmid library of R. leguminosarum DNA in E. coli was that described by Lamb et al. (1985). The library was transferred en masse to $R$. leguminosarum, selecting for transconjugants on $Y$ medium containing tetracycline, streptomycin and kanamycin, as well as hesperetin plus X-P to identify clones with increased levels of nodC-pbo $A$ expression in strain A131.

Mutagenesis of cosmid clones was carried out as described by Surin et al. (1990) using E. coli strain A118 and selecting for Tn 5 -lac $Z$ insertions following conjugation into strain 8401 . The Tn5-lac $Z$ alleles were recombined from plasmids into the $R$. leguminosarum chromosomal dct genes by homologous recombination as described by Ruvkun \& Ausubel (1981); recombinants were checked for the appropriate pattern of fragments by DNA hybridizations.

Transposon mutagenesis of strain A146 was carried out using the suicide plasmid pSUP102-Gm carrying $\operatorname{Tn} 5-$ lac $Z$ as described by Simon et al. (1989), selecting for transconjugants on TY medium containing kanamycin and streptomycin. Single colonies were then screened for growth on $\mathrm{Y}$ medium containing succinate plus $\mathrm{NH}_{4} \mathrm{Cl}$. The mutations in the dct region were recombined onto $\mathrm{pIJ1848}$ by preparing plasmid DNA and transforming E. coli to kanamycin and tetracycline resistance.

DNA manipulations. Restriction enzyme digests, and ligations and subclonings were done following the methods of Maniatis et al. (1982). Plasmid pIJ1885 was made by digesting pIJ1848 with HindIII and re-ligating the DNA and screening for DNA fragments present. Only a $10 \mathrm{~kb}$ HindIII fragment was released by HindIII digestion of pIJ1885. This plasmid was digested with $A c c \mathrm{I}$, and a $4.4 \mathrm{~kb}$ fragment was subcloned in either orientation into phagemid Bluescript SK $(+)$ (Stratagene) to form pIJ1933 and pIJ1934.

PCR amplification of DNA from pIJ1991 and A146 was done using the oligonucleotide 5' GGAGGTCACATGGAAGTCAG, which is homologous to nucleotides $46-65$ from the end of $\operatorname{Tn} 5$, and the oligonucleotide 5' CGGCACCCCGTCCTACGTCG, which is homologous to nucleotides 759-778 of the $\operatorname{dct} B$ region as described by Ronson et al. (1987). Following an initial denaturation for $5 \mathrm{~min}$ at $93{ }^{\circ} \mathrm{C}$, conditions were 34 cycles of $45 \mathrm{~s}$ at $93{ }^{\circ} \mathrm{C}, 45 \mathrm{~s}$ at $58^{\circ} \mathrm{C}$, and then $2.5 \mathrm{~min}$ at $72^{\circ} \mathrm{C}$. The $30 \mu \mathrm{l}$ reaction mixture contained $20 \mathrm{mM}$ Tris $/ \mathrm{HCl}, \mathrm{pH} 8 \cdot 0$, $3 \mathrm{mM} \mathrm{MgCl}, 0 \cdot 2 \mathrm{mM}$ each of dATP, dCTP, dGTP and d'T'T, $0.025 \%(\mathrm{v} / \mathrm{v})$ Tween Nonidet and $1 \mu \mathrm{l}$ Taq polymerase.

DNA sequencing was done with a Pharmacia Automated Low Fluorescent DNA Sequencer using single-stranded DNA from nested deletions created from pIJ1933 and pIJ1934. DNA 
Table 1. R. leguminosarum strains and plasmids

\begin{tabular}{|c|c|c|}
\hline Strain or plasmid & Relevant characteristics & Reference/source \\
\hline 8401 & R. leguminosarum lacking a symbiotic plasmid; $\mathrm{Str}^{\mathrm{R}}$ & Lamb et al. (1982) \\
\hline A34 & $\begin{array}{l}\text { Derivative of } 8401 \text { carrying pRL1 JI (previously called } \\
8401 / \text { pRL1 JI) }\end{array}$ & Downie et al. (1983) \\
\hline A97 & Derivative of A34 carrying nodO94::'Tn5-lacZ & Economou (1990) \\
\hline A131 & Derivative of A34 carrying nodC97:: $\operatorname{Tn} 5$-pho $A$ & Economou (1990) \\
\hline A146 & $\begin{array}{l}\text { Derivative of } 8401 \text { carrying a mutation that affects nod gene } \\
\text { expression }\end{array}$ & This work \\
\hline A150 & Derivative of A146 containing pRL1 JI carrying nodC97:: $\operatorname{Tn} 5-p h o A$ & This work \\
\hline A155 & Derivative of A146 containing pRL1 JI carrying nodO94:: Tn5-lacZ & This work \\
\hline A214 & Derivative of A146 containing pJB5JI, (pRL1JI::Tn5) & This work \\
\hline A273 & Derivative of 8401 carrying $d c t A 21:: \operatorname{Tn} 5$-lac $Z$ & This work \\
\hline A274 & Derivative of 8401 carrying $d c t B 44:: \operatorname{Tn} 5-\operatorname{lac} Z$ & This work \\
\hline A275 & Derivative of 8401 carrying $d c t B 5:: \operatorname{Tn} 5-l a c Z$ & This work \\
\hline A276 & Derivative of 8401 carrying $\operatorname{dct} B 15:: \operatorname{Tn} 5-\operatorname{lac} Z$ & This work \\
\hline A281 & $\begin{array}{l}\text { Suc derivative of A146 isolated after mutagenesis with pSUP102- } \\
\text { Gm::Tn5-lac } Z\end{array}$ & This work \\
\hline pIJ1089 & cloned nod $A B C D I J F E L M N T O$ genes from R. l. viciae & Downie et al. (1983) \\
\hline pIJ1478 & nodD-lac $Z$ translational fusion & Rossen et al. (1985) \\
\hline pIJ1687 & Derivative of pIJ1089 carrying nodC97: : Tn 5-pbo $A$ & Economou (1990) \\
\hline pI J1848 & $\begin{array}{l}\text { Cosmid clone that complements the mutation in } \mathrm{A} 146 \text {, carries } \\
\operatorname{dct} A B D\end{array}$ & This work \\
\hline pIJ1849 & As pIJ1848, with which it overlaps & This work \\
\hline pIJ1885 & $\begin{array}{l}\text { Deleted derivative of pIJ1848 contains a } 10 \mathrm{~kb} \text { HindIII fragment, } \\
\text { carries } \operatorname{dct} A B D\end{array}$ & This work \\
\hline pIJ1933 & $4.4 \mathrm{~kb}$ AccI from pI J1885 subcloned in Bluescript $\mathrm{SK}(+)$ & This work \\
\hline pIJ1934 & As pIJ1933 but in the opposite orientation & This work \\
\hline pIJ1968 & Derivative of pIJ1848 carrying $\operatorname{dct} B 5:: \operatorname{Tn} 5-\operatorname{lac} Z$ & This work \\
\hline pIJ1969 & Derivative of pIJ1848 carrying $d_{c t B} 15:$ : Tn $5-$ lac $Z$ & This work \\
\hline pIJ1970 & Derivative of $\mathrm{pIJ} 1848$ carrying $\operatorname{dct} A 21:$ : $\operatorname{Tn} 5-\operatorname{lac} Z$ & This work \\
\hline pIJ1971 & Derivative of pIJ1848 carrying $d c t B 44:: \operatorname{Tn} 5-l a c Z$ & This work \\
\hline pIJ1991 & Derivative of pIJ1848 containing the mutated region from A281 & This work \\
\hline pSUP102-Gm & $\mathrm{Tet}^{\mathrm{R}} \mathrm{Gm}^{\mathrm{R}}$, does not replicate in $\mathrm{R}$. leguminosarum & Simon et al. (1989) \\
\hline pSUP102-Gm:: Tn5-lac Z & Derivative of pSUP102-Gm carrying Tn5-lac $Z$ & Simon et al. (1989) \\
\hline
\end{tabular}

probes for hybridizations were labelled with ${ }^{32} \mathrm{P}$ by random priming of DNA fragments.

Nodulation tests. Measurements of nodulation and acetylene reduction by nodulated roots of peas were done as described by Johnston \& Beringer (1975). Five-day-old nodules were prepared for light microscopy as described by Beringer et al. (1977).

\section{RESULTS AND DISCUSSION}

\section{Isolation of a mutant with lowered nod gene expression}

R. leguminosarum strain 8401 , which lacks a symbiotic plasmid, was mutagenized with NTG. A plasmid (pIJ1687) carrying the entire nod gene region and the nodC97:: $\operatorname{Tn} 5$-pho $A$ allele, was transferred into the mutagenized population by conjugation; the transconjugants were then plated onto succinate minimal medium $(\mathrm{Y})$ plates supplemented with streptomycin plus kanamycin (to select transconjugants), hesperetin to induce the nod genes, and X-P to monitor the level of PhoA activity resulting from the expression of the NodC-PhoA fusion.

Of about 10000 colonies screened, one that appeared pale blue compared with the background of dark blue colonies was confirmed to have a reduced level of PhoA activity by a quantitative assay in liquid medium. The reporter gene construct was then cured from the strain by screening for the loss of tetracycline resistance to yield mutant A146. When pIJ1687 was reintroduced into A146, the level of flavonoid-inducible $\mathrm{PhoA}$ was much less than that seen with colonies of the control (8401/pIJ1687), confirming that the mutation was in A146 rather than pIJ1687.

A derivative of pRL1JI containing the nodC97::Tn5pho $A$ allele was introduced into $\mathrm{A} 146$ by conjugation to form strain A150, and in parallel a different reporter system ( $\beta$-galactosidase) was also introduced into A146 
Table 2. Levels of nod gene induction in $R$. leguminosarum

The results shown are the means $( \pm \mathrm{SD})$ of five assays. - , Not applicable.

\begin{tabular}{|c|c|c|c|c|}
\hline \multirow[t]{3}{*}{ Strain } & \multirow{2}{*}{\multicolumn{2}{|c|}{$\begin{array}{c}\begin{array}{c}\text { Alkaline phosphatase } \\
\text { (units) }\end{array} \\
\text { Hesperetin }\end{array}$}} & \multirow{2}{*}{\multicolumn{2}{|c|}{$\begin{array}{c}\begin{array}{c}\beta \text {-Galactosidase } \\
\text { (units) }\end{array} \\
\text { Hesperetin }\end{array}$}} \\
\hline & & & & \\
\hline & - & + & - & + \\
\hline $8401 / \mathrm{pRL} 1 \mathrm{JI}$, nodC-pho $A$ & $32 \pm 3$ & $660 \pm 33$ & - & - \\
\hline A146/pRL1 JI, nodC-pho $A$ & $21 \pm 1$ & $169 \pm 55$ & - & - \\
\hline $8401 / \mathrm{pRL} 1 \mathrm{JI}, \operatorname{nodO}-\mathrm{lac} Z$ & - & - & $76 \pm 8$ & $2305 \pm 83$ \\
\hline A146/pRL1 JI, nodO-lacZ & - & - & $65 \pm 3$ & $592 \pm 76$ \\
\hline $8401 / \mathrm{pIJ} 1478$, nodD-lac $Z$ & - & - & $541 \pm 39$ & - \\
\hline A146/pIJ1478, nodD-lacZ & - & - & $317 \pm 12$ & - \\
\hline $8401 / \mathrm{pRL} 1 \mathrm{JI} / \mathrm{pIJ} 1478, \operatorname{nodD}-\mathrm{lacZ}$ & - & - & $390 \pm 51$ & - \\
\hline A146/pRL1 JI/pIJ1478, nodD-lacZ & - & - & $258 \pm 19$ & - \\
\hline
\end{tabular}

using the nodO94::Tn5-lac $Z$ allele on pRL1 JI to form strain A155. As shown in Table 2, the levels of flavonoidinducible $\beta$-galactosidase or PhoA in the mutant were about one-third of those of the isogenic control strains A131 (8401/pRL1JI, nodC97::Tn5-pho A) and A97 (8401/pRL1 JI, nodO94:: Tn5-lacZ). Since the reduction is seen with both reporter systems, the mutation must influence nod gene expression rather than, for example, processing of PhoA.

The level of nodD expression in A146 was measured by introducing the nodD-lac $Z$ gene fusion on $\mathrm{pIJ1478.} \mathrm{This}$ revealed that the level of nodD expression was about $60 \%$ of normal (Table 2), indicating that the effect of the mutation was to reduce nodD expression rather than affecting NodD-mediated regulation (e.g. flavonoid uptake or processing). In R. l. viciae, NodD normally represses transcription from the nodD promoter (Rossen $e t$ al., 1985); the introduction of nodD (on pRL1 JI) into the mutant carrying pIJ1478 revealed that similar repression was maintained in the mutant (Table 2).

\section{Effects of the mutation on symbiotic phenotype}

pJB5JI is a derivative of pRL1JI carrying Tn5 in a bacteriocin gene, and it confers normal nodulation and nitrogen-fixation abilities on strains such as 8401 which lack a symbiotic plasmid (Johnston et al., 1978). When strain A214, a derivative of A146 carrying pJB5JI, was inoculated onto pea seedlings, nodules appeared at the normal time but were smaller and more numerous than with the control strain (8401/pJB5JI). The nodules were pale pink or green (compared with the normal reddishpink colour), and older plants had pale green leaves. These characteristics are typical of peas with abnormal nitrogen fixation. The nodules formed by the mutant were only $5-20 \%$ as effective as the control in reducing acetylene.

Electron microscopy of thin sections of young nodules revealed that normal infection threads were present, but
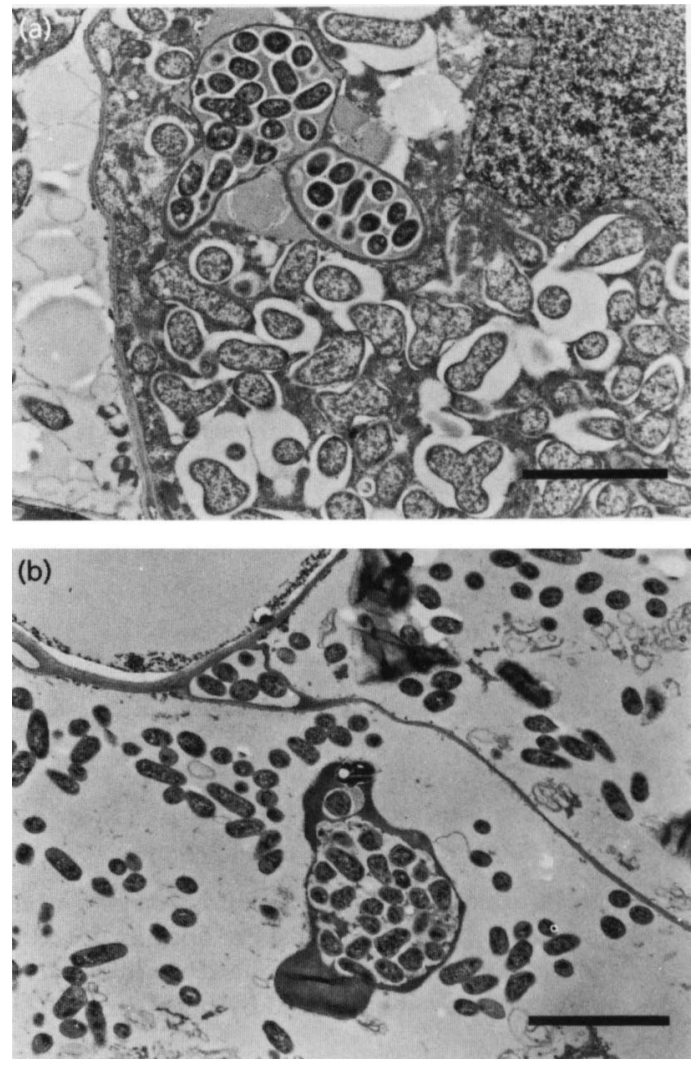

Fig. 1. Electron micrographs of thin sections of pea nodules induced by (a) the control strain A34 and (b) the mutant A214 (A146 carrying pJB5J). Bar, $4 \mu \mathrm{m}$.

the number of bacteria within infected nodule tissue was much lower than normal; those bacteria present seemed to lack the normal plant-made peribacteroid membrane (Fig. 1). Therefore the mutation seemed to have blocked normal bacteroid development. 
Allele-specific $d c t B$ mutation lowers nod expression

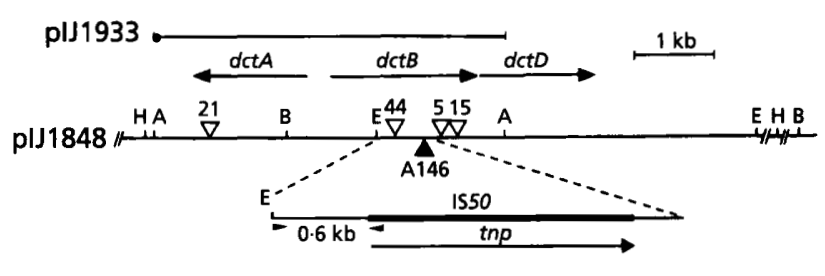

Fig. 2. Map of the region from plJ1848 which complements A146. The $4.4 \mathrm{~kb}$ Accl region sequenced on plJ1933 is indicated and the deduced positions of the open reading frames encoding $\operatorname{dct} A, \operatorname{dct} B$ and $\operatorname{dct} D$ are shown. The open triangles indicate the positions of the $\operatorname{dct} A 21, \operatorname{dctB44}, \operatorname{dctB5}$ and $\operatorname{dctB} 15$ alleles mapped on plJ1970, pIJ1971, plJ1968 and pIJ1969, respectively. The filled triangle represents the mapped location of the element that caused the mutation in A146. The enlarged region illustrates the position (arrowheads) of the oligonucleotides used to map the insertion. The location of the deduced 1550 insertion element is indicated (heavy line), and the arrow shows the direction of transcription of the transposase (tnp) encoded on IS50R.

\section{Characterization of the mutated region in A146}

Strain A150 (the derivative of A146 carrying the nodC97::Tn5-pho $A$ allele on pRL1 JI) was used as a recipient in a conjugation with a population of $E$. coli containing random cosmid clones of $R$. leguminosarum DNA, and the transconjugants were screened on minimal medium containing hesperitin plus $\mathrm{X}-\mathrm{P}$ to monitor induction of nodC-pho $A$. Two overlapping plasmids, pI J1848 and pI J1849, were identified which could restore normal flavonoid-inducible nod $C$-pho $A$ expression to A150. When either of these plasmids was transferred to strain A155 (A146/pRL1 JI, nodO93:: Tn5-lacZ), normal levels of flavonoid-inducible $\beta$-galactosidase were restored. Both pI J1848 and PI J1849 also complemented the nitrogen-fixation defect of A146/pJB5JI. Therefore the region of DNA common to pIJ1848 and pIJ1849 complements both nod gene induction and nitrogen fixation, indicating that both phenotypes result from either a single mutation or closely linked mutations.

pIJ1848 was mutagenized with $\operatorname{Tn} 5-l a c Z$ and mutated derivatives were screened on plates for their ability to complement flavonoid-inducible nod $C$-pho $A$ expression in strain A150. From about 700 independent mutant plasmids, four were identified (pI J1968, pI J1969, pI J1970 and $\mathrm{pI} \mathrm{J1971)} \mathrm{that} \mathrm{were} \mathrm{unable} \mathrm{to} \mathrm{complement} \mathrm{flavonoid-}$ inducible nodC-pho $A$ expression. DNA from each was digested with a variety of restriction enzymes; all four gave different patterns, each consistent with insertion of a single transposon. Using a variety of techniques, including digests with combinations of restriction enzymes, subcloning and DNA hybridizations, the sites of transposon insertions were mapped and found to be in a $4 \mathrm{~kb}$ region within a $10 \mathrm{~kb}$ HindIII fragment (Fig. 2) which was subcloned. Further mapping identified a $4.4 \mathrm{~kb} A c c \mathrm{I}$ fragment that spanned the region in which the four transposon-induced mutations were located (Fig. 2).

The $4.4 \mathrm{~kb}$ AccI fragment was subcloned in both orientations in Bluescript SK(+) to form pIJ1933 and
Table 3. Succinate uptake in $R$. leguminosarum

\begin{tabular}{|lcc|}
\hline Strain & $\begin{array}{c}\text { Succinate uptake } \\
\text { [nmol } \text { min }^{-1} \text { (mg protein) } \\
\text { after growth on: }\end{array}$ \\
\cline { 2 - 3 } & Glucose $+\mathbf{N H}_{\mathbf{4}}^{+}$ & Glucose + aspartate \\
\hline 8401 & $7 \cdot 1$ & $43 \cdot 0$ \\
A146 & $25 \cdot 9$ & $23 \cdot 0$ \\
A277 $($ dct $A)$ & $0 \cdot 5$ & $4 \cdot 7$ \\
A275 $(d c t B)$ & $2 \cdot 5$ & $0 \cdot 7$ \\
A281 & $2 \cdot 4$ & $0 \cdot 0$ \\
\hline
\end{tabular}

pIJ1934. A set of nested deletions of each was made, and the DNA sequence was determined over most of the region. When this sequence and a translation of it were used to search for related sequences in the EMBL and GenBank databases, near identity ( $>98 \%$ ) was found with the $d c t$ gene region sequenced by Ronson $e t$ al. (1987a) from another strain of R.l. viciae, and high homology (approximately $80 \%$ ) was found with the $\operatorname{dct} A$ and $d_{c t} B$ genes from $R$. meliloti. The deduced positions of the $\operatorname{dct} A, \operatorname{dct} B$ and $\operatorname{dct} D$ open reading frames are shown in Fig. 2. Three of the four mutations identified are in the $\operatorname{dct} B$ gene, and one is in $\operatorname{dct} A$. These two genes are in different operons, $\operatorname{dct} B$ being one of two genes controlling $\operatorname{dct} A$ expression. The observation that derivatives of pIJ1848 mutated in $\operatorname{dct} B$ or $\operatorname{dct} A$ cannot complement the mutation in A146, indicates that this mutation may affect both $\operatorname{dct} B$ and $\operatorname{dct} A$.

\section{Measurements of succinate-dependent growth and succinate transport}

The nature of the gene region identified was very surprising since the original mutant A146 had been isolated following a screen on $\mathrm{Y}$ medium containing succinate as $\mathrm{C}$-source and glutamate as $\mathrm{N}$-source; a dct mutant would not be expected to grow well on this medium (Ronson et al., 1981). The growth of A146 in liquid minimal medium containing succinate and $\mathrm{NH}_{4}^{+}$as the $\mathrm{N}$-source was measured and found to be normal (data not shown).

The rates of succinate uptake were measured in cells grown in minimal medium with glucose plus $\mathrm{NH}_{4}^{+}$; surprisingly, the mutant had an uptake rate considerably higher than the control (Table 3). Under these growth conditions the $d c t$ transport system is not normally strongly induced (Watson et al., 1993). Since aspartate is an efficient inducer of the dct genes (Watson $e t$ al., 1993), the cells were grown on glucose plus aspartate (instead of $\mathrm{NH}_{4}^{+}$) as the $\mathrm{N}$-source. This resulted in a strong induction of succinate transport in the control (8401), but had no effect in the mutant A146. Therefore A146 contains a mutation that causes constitutive expression of succinate uptake and does not reduce its ability to grow on succinate. 


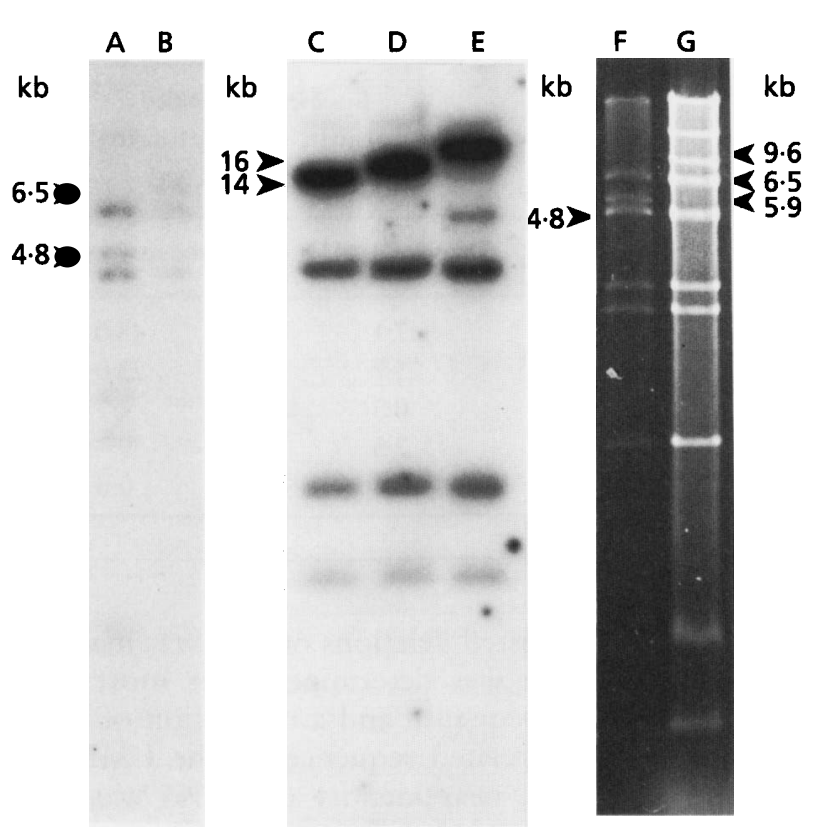

Fig. 3. Analysis of the DNA mutated in R. leguminosarum A146 and A281. Lanes A-E are autoradiographs of genomic DNA obtained following hybridization using ${ }^{32}$ P-labelled pIJ1848 as a probe. Lanes: A, 8401 DNA cut with EcoRI; B, A146 DNA cut with EcoRI; C, 8401 DNA cut with BamHI; D, A146 DNA cut with BamHI; E, A281 DNA cut with BamHI. Lanes F and G, an ethidium-bromide-stained gel of EcoRI-digested DNA from pIJ1848 and plJ1991, respectively. The sizes of relevant fragments are indicated in $\mathrm{kb}$.

\section{Mutagenesis of A146 to isolate Suc mutants and the phenotypes of other dct mutants}

In view of the above results, we thought that there might be two succinate transport systems in the parental strain, one of which was being expressed constitutively in A146. This was addressed in two ways. The $\operatorname{dct} A$ allele from pIJ1970 and the $\operatorname{dct} B$ alleles from pIJ1968, pIJ1969 and pIJ1971 were transferred by homologous recombination into the chromosome of 8401 . The resulting strains were tested for growth and uptake of succinate. A277 (carrying the $\operatorname{dct} A$ allele) did not grow on succinate and had no (or at most, very low) succinate uptake (Table 3). A275 (carrying one of the $\operatorname{dct} B$ alleles) grew very slowly on succinate $/ \mathrm{NH}_{4}^{+}$agar plates and had a very low level of succinate uptake (Table 3). Therefore mutations in $\operatorname{dct} A$ or $d c t B$ abolished (or severely lowered) succinate growth and uptake in these strains, indicating that there are not two succinate transport systems in 8401. An alternative strategy was to mutagenize A146 with Tn5-lacZ and screen for Suc ${ }^{-}$mutants. A surprisingly high frequency $(1 \%)$ of Suc ${ }^{-}$mutants was found among the progeny of the mutagenesis by the suicide plasmid pSUP102Gm::Tn5-lacZ. One such mutant was called A281 and shown to have very low (if any) succinate uptake when grown with or without aspartate to induce the dct genes (Table 3). Like several other Suc ${ }^{-}$mutants isolated after mutagenesis of A146, A281 had a much higher frequency of reversion to $\mathrm{Suc}^{+}$than expected or

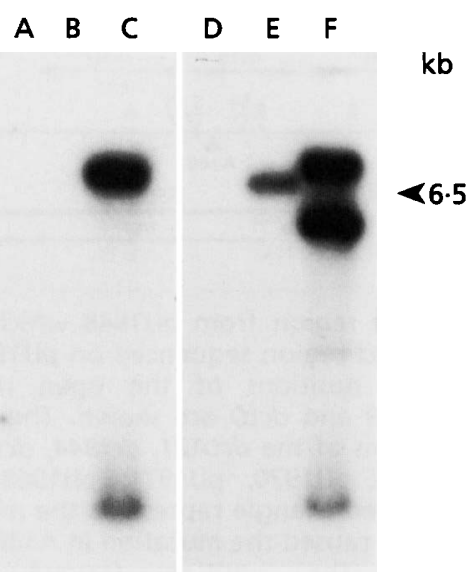

Fig. 4. Identification of part of Tn5 in R. leguminosarum A146. Autoradiographs of hybridizations with 32P-labelled pSUP102Gm, (lanes A-C) and hybridizations with ${ }^{32}$ P-labelled pSUP202Gm::Tn5 (lanes D-F). EcoRI-digested DNA was from strain 8401 (lanes A and D), strain A146 (lanes B and E) and strain A281 (lanes $C$ and $F$ ).

seen with other Suc ${ }^{-}$dct mutants such as A275 or A277. Strain A281 could be restored to normal growth by pIJ1848 carrying the dct region.

The high frequency of appearance of $\mathrm{Suc}^{-}$mutants following mutagenesis of A146, and their relatively high reversion rates, indicated that some rearrangements may have occurred at the dct locus. EcoRI- or BamHI-digested DNA from A146 and the control 8401 was probed with $\mathrm{pIJ1848.} \mathrm{This} \mathrm{revealed} \mathrm{that} \mathrm{the} \mathrm{Bam} \mathrm{HI} \mathrm{fragment} \mathrm{of} \mathrm{about}$ $14 \mathrm{~kb}$ in 8401 was increased in size (to about $16 \mathrm{~kb}$ ) in A146 and that an EcoRI fragment of $4.8 \mathrm{~kb}$ was replaced by a fragment of $6.5 \mathrm{~kb}$ (Fig. 3). This $4.8 \mathrm{~kb}$ EcoRI fragment corresponds to that carrying part of $d c t B$ plus $d c t D$ (Fig. 2). Therefore the original mutation in A146 was probably caused by the insertion of an approximately $1.7 \mathrm{~kb}$ fragment. The presence of this insertion was unexpected since A146 had been mutagenized with NTG. However, the phenotype had been identified following the introduction of pIJ1687 carrying $\operatorname{Tn} 5-p h o A$, a derivative of $\mathrm{Tn} 5$, in nodC. Therefore it was theoretically possible that the insertion might have arisen from

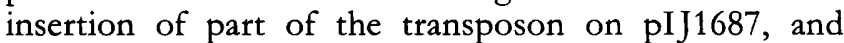
significantly the IS50R element from $\operatorname{Tn} 5-p h o A$ is $1.7 \mathrm{~kb}$ in size (Reznikoff, 1993). Hybridization with the $d c t$ region on pIJ1848 revealed that the mutation in A281 caused a further alteration, with the approximately $16 \mathrm{~kb}$ BamHI fragment being replaced by a larger fragment (Fig. 3). These observations could be explained if Tn5lac $Z$ on the suicide plasmid had recombined with a region of homology (e.g. IS50) in the dct region in A146. Such a recombination-mediated mutation could explain the high frequency of appearance of Suc mutants, and the resolution of such a cointegrate by recombination would result in a relatively high level of Suc ' 'revertants'.

EcoRI-digested DNA from 8401, A146 and A281 was probed with the vector pSUP102-Gm and a derivative of it carrying Tn5 (Fig. 4). As expected, no hybridization 
was seen in either case with DNA from 8401. With A146, a hybridizing band was seen only when the derivative carrying $\operatorname{Tn} 5$ was used as a probe, confirming that part of Tn5 was present in A146. This $6.5 \mathrm{~kb}$ fragment is the same size as the novel fragment identified in A146 using a $d_{c} t B$ gene probe. With the 'double' mutant A281, hybridization was seen with both pSUP102-Gm and pSUP102-Gm:: $\operatorname{Tn} 5$ (Fig. 3). The different patterns seen with 8401, A146 and A281 are consistent with the hypothesis that the entire replicon (pSUP102-Gm including Tn5-lacZ) had integrated into A146 to form A281, and mutant A281 was indeed found to be resistant to gentamicin (presumably from pSUP102-Gm).

The mutated region from A281 was recombined into pIJ1848 by preparing DNA from A281/pIJ1848 and using it to transform E. coli, selecting for resistance to both tetracycline (on pI J1848) and kanamycin (on Tn5lac $Z$ ). The sizes of EcoRI fragments in plasmids from several transformants were found to be identical. The results with one representative clone (pIJ1991) are shown in Fig. 3. The $4.8 \mathrm{~kb} E c o \mathrm{RI}$ fragment containing the $\operatorname{dct}_{\mathrm{B}} \mathrm{BD}$ gene region is replaced by three novel fragments of sizes $5.9 \mathrm{~kb}$ (seen as a doublet), $6.5 \mathrm{~kb}$ and $9.6 \mathrm{~kb}$. This would be consistent with the integration of pSUP102-Gm:: Tn5lac $Z$ into A146 to form A281, and the entire region being recombined onto pIJ1848 to form pIJ1991. Also compatible with this idea were the observations that pIJ1991 carries gentamicin resistance (from pSUP102-Gm), and that in E. coli, pIJ1991 appeared to have a higher copy number than pI J1848, presumably as a result of the increased level of replication conferred by the pSUP102$\mathrm{Gm}$ replicon.

We made the assumption that the initial mutation in A146 was caused by IS 50 from the $\operatorname{Tn} 5-p h o A$, and that the subsequent event in A281 was recombination via IS50 sequences in A146 and pSUP102-Gm::Tn5-lacZ. Restriction mapping indicated that the initial insertion must be at the left end of the $4.8 \mathrm{~kb}$ EcoRI fragment, within $\operatorname{dct} B$. A PCR was done using one primer homologous to $d_{c t} B$, close to the EcoRI site in the $4.8 \mathrm{~kb} E c o \mathrm{RI}$ fragment, and a second primer homologous to the end of IS50, priming outward (Fig. 2). With DNA from A146 and pIJ1991, a $0.6 \mathrm{~kb}$ fragment was found, whereas no products were found with either of the single primers. The insertion event is therefore most probably about $0.6 \mathrm{~kb}$ from the EcoRI site, about 1200 nucleotides downstream of the ATG that initiates the 1866-nucleotide sequence predicted to encode DctB.

\section{Allele-specificity effect on nod gene induction}

Other mutations have been described within $\operatorname{dct} B$, but no effects on nod gene induction have been reported. The nodD-lac $Z$ fusion on $\mathrm{pIJ1478}$, and the nodC-pho $A$ fusion on pIJ1687, were each transferred to the $d t t B$ mutant strain $\mathrm{A} 275$ and the $\operatorname{dct} A$ and $\operatorname{dct} B$ mutant derivatives (CR534 and CR535, respectively) from another strain (3855) of R. l. viciae (Ronson et al., 1984). In each case, the levels of nod gene induction with the $d c t$ mutants were similar to those for the isogenic control strains.
The R. leguminosarum transducing phage RL38 was plated on the $\operatorname{dctB}$ mutant $A 275$ and used to transduce A146 to kanamycin resistance. The levels of nodD expression and nodC gene induction in 20 transductants were measured after transferring pIJ1478 and pIJ1687 into them. In each case, nod gene expression levels were normal in the transductants. Replacement of the dctB allele in A146 with the dctB5::Tn5-lacZ allele from A275 was accompanied by restoration of normal nod gene induction, thus confirming linkage between the mutation in the $\operatorname{dct} B$ region of A146 and the lowered nod gene induction. This also reconfirmed that the 'normal' $d c t B$ mutation in A275 does not influence either nodD expression or nodC induction. Therefore the effect of the mutation in A146 on nod gene induction is allele-specific.

It is not immediately obvious why a mutation in $\operatorname{dct} B$ should have an effect on nod gene expression. DctB along with DctD is required for the succinate-dependent induction of $\operatorname{dct} A$ (Ronson et al., 1987b; Yarosh et al., 1989 ; Jiang et al., 1989). $d c t B$ is also required for aspartatedependent induction of succinate transport (Watson et al., 1993). The mutation in A146 appears to cause constitutive succinate uptake. However, although this mutation allows succinate uptake (at a level about $50 \%$ of that seen after maximal induction with aspartate), the ability of the mutant to fix nitrogen in nodules is severely impaired.

It would appear that the regulation of the $\operatorname{dct} A$ gene is complex, because in addition to regulatory effects of the two-component regulatory system encoded by $d c t B$ and $\operatorname{dct} D$, mutation of $\operatorname{dct} A$ itself causes high-level expression from the $\operatorname{dct} A$ promoter, even in cells not exposed to dicarboxylic acids (Ronson \& Astwood, 1985; Yarosh $e t$ al., 1989; Jiang et al., 1989). The high level of succinate transport in A146 grown on medium containing glucose plus $\mathrm{NH}_{4}^{+}$indicates that the $\operatorname{dct} A$ gene is probably expressed at a high level. In this regard the mutation is analogous to the effect of a $\operatorname{dct} A$ mutation, but evidently in A146 the $\operatorname{dct} A$ gene product is functional since high levels of succinate transport are observed. In fact it is rather surprising that although the mutation appears to cause constitutive succinate transport, nitrogen fixation by mutant bacteroids is severely impaired. Thus, although succinate uptake is necessary for nitrogen fixation, it appears that higher-level, or properly regulated, expression is required.

The mutation of $d_{c t} B$ in $A 146$ appears to be allele-specific since other mutations in $d_{c t} B$ do not have a similar effect on nod gene expression. Such allele specificity could be explained at the DNA level, e.g. by the creation of a promoter that causes constitutive $\operatorname{dct} A$ expression, and such an effect would be consistent with the complementation observations which indicate that the mutation in $d c t B$ has a cis effect on $d c t A$. To address the possibility that constitutive expression of $\operatorname{dct} A$ reduces the expression of nodD and other nod genes, plasmid pRU296 (which carries $\operatorname{dct} A$ expressed constitutively from the neomycin phosphotransferase promoter in the vector pML122) was transferred to strains $8401 / \mathrm{pIJ} 1478$ (nodD-lac Z) and A97 (nodO-lac $Z$ ). The levels of nod gene expression were measured as described in Table 2 and found to be normal; 
strain $8401 / \mathrm{pIJ} 1478 / \mathrm{pRU} 296$ expressed $524( \pm 42)$ units of $\beta$-galactosidase activity, and strain A97/pRU296 expressed $2286( \pm 92)$ units of $\beta$-galactosidase after growth in the presence of hesperetin. Therefore it is unlikely that the reduction in nod gene expression in A146 is simply due to constitutive $\operatorname{dct} A$ expression.

An alternative explanation for the allele-specific nature of the $\operatorname{dct} B$ mutation in $A 146$ is that a truncated $\operatorname{DctB}$ protein (or proteins) might be made. The estimated position of the putative IS 50 mutation in A146 is such that it could result in the formation of a derivative of $\mathrm{Dct} B$ which lacks the domain that normally interacts with DctD, but could retain the two membrane-spanning regions that locate a large loop of DctB in the periplasm. It is also possible that only the C-terminal part of DctB could be formed, and such a deleted protein might retain auto-phosphorylation activity and phosphorylate DctD, resulting in constitutive $\operatorname{dct} A$ expression. Such a mutant $\mathrm{DctB}$ protein might even phosphorylate other analogous regulatory proteins. Sanjuan et al. (1994) have demonstrated that the nodD1 gene in Bradyrbizobium japonicum is under the control of the nod $V$ and nodW genes, which encode a two-component regulatory system analogous to that encoded by $d c t B$ and $d_{c t} D$. If similar regulation of nodD were present in $R$. leguminosarum, it is possible that a truncated form of DctB might alter the phosphorylation state of a transcriptional activator such as NodW, and this could result in lowered nodD expression. Such a model is consistent with the allele-specific nature of the $\operatorname{dct} B$ mutation in $A 146$. However it does not necessarily explain why the mutation in A146 should have a cis effect on $\operatorname{dct} A$. This might be explained if there were normally some interaction between Dct $A$ and DctB, and an abnormal interaction occurred between DctA and a deleted form of DctB.

\section{ACKNOWLEDGEMENTS}

We are indebted to C. J. Reid (University of Reading) for making available pRU296 before publication, and to A. Economou, whose gift of plasmids and advice made this project possible. R. Simon also kindly provided strains and plasmids. We also thank A. Cavill for DNA sequencing, our colleagues C. Marie and E. Schoonejans for stimulating discussions, and D. A. Hopwood for his critical comments on the manuscript. The work was supported by AFRC grant PG208/548, a grant-in-aid from the AFRC, an EC training fellowship and a John Innes Foundation Studentship to A. M.

\section{REFERENCES}

Baev, N., Amar, M., Defez, R. \& laccarino, M. (1992). The expression of the nodD and nod $A B C$ genes of Rhizobium leguminosarum is not regulated in response to combined nitrogen. FEMS Microbiol Lett 97, 205-208.

Beringer, J. E. (1974). R factor transfer in Rhizobium leguminosarum. $J$ Gen Microbiol 84, 188-198.

Beringer, J. E., Johnston, A. W. B. \& Wells, B. (1977). The isolation of conditional ineffective mutants of Rhizobium leguminosarum. J Gen Microbiol 98, 339-343.

Buchanan-Wollaston, V. (1979). Generalized transduction in Rbizobium leguminosarum. J Gen Microbiol 112, 135-142.

Burn, J. E., Rossen, L. \& Johnston, A. W. B. (1987). Four classes of mutations in the nodD gene of Rbizobium leguminosarum biovar viciae that affect its ability to autoregulate and/or activate other nod genes in the presence of flavonoid inducers. Genes \& Dev 1, 456-464.

Cubo, T., Economou, A., Murphy, G., Johnston, A. W. B. \& Downie, J. A. (1992). Molecular characterization and regulation of the rhizosphere-expressed genes $r b i A B C R$ that can influence nodulation by Rbizobium leguminosarum biovar viciae. J Bacteriol 174, 4026-4035.

Djordjevic, M. A., Redmond, J.W., Batley, M. \& Rolfe, B. G. (1987). Clovers secrete specific phenolic compounds which either stimulate or repress nod gene expression in Rbizobium trifolii. EMBO J 6, 1173-1179.

Downie, J. A. (1991). A nod of recognition. Curr Biol 1, 382-384.

Downie, J. A., Ma, Q.-S., Knight, C. D., Hombrecher, G. \& Johnston, A. W. B. (1983). Cloning of the symbiotic region of Rbizobium leguminosarum: the nodulation genes are between the nitrogenase genes and the nif $A$-like gene. EMBO J 2, 947-952.

Dusha, I. \& Kondorosi, A. (1993). Genes at different regulatory levels are required for the ammonia control of nodulation in Rhizobium meliloti. Mol \& Gen Genet 240, 435-444.

Economou, A. (1990). Genetic analysis of a region of the Rhizobium leguminosarum Sym plasmid $p \mathrm{RL} 1 \mathrm{JI}$. PhD thesis, University of East Anglia, UK.

Figurski, D. H. \& Helinski, D. R. (1979). Replication of an origincontaining derivative of plasmid RK2 dependent on a plasmid function provided in trans. Proc Natl Acad Sci US A 76, 1648-1652.

Firmin, J. L., Wilson, K. E., Rossen, L. \& Johnston, A. W. B. (1986). Flavonoid activation of nodulation genes in Rhizobium reversed by other compounds present in plants. Nature 324, 90-92.

Göttfert, M. (1993). Regulation and function of rhizobial nodulation genes. FEMS Microbiol Rev 104, 39-64.

Hong, G.-F., Burn, J. E. \& Johnston, A. W. B. (1987). Evidence that DNA involved in the expression of nodulation nod genes in Rhizobium, binds to the product of the regulatory gene nodD. Nucleic Acids Res 15, 9677-9690.

Jiang, J., Gu, B., Albright, L. M. \& Nixon, B. T. (1989). Conservation between coding and regulatory elements of Rbizobium meliloti and Rhizobium leguminosarum dct genes. J Bacteriol 171, 5244-5253.

Johnston, A. W. B. \& Beringer, J. E. (1975). Identification of the Rhizobium strains in pea root nodules using genetic markers. $J$ Gen Microbiol 87, 343-350.

Johnston, A. W. B., Beynon, J. L., Buchanan-Wollaston, A. V., Setchell, S. M., Hirsh, P. \& Beringer, J. E. (1978). High frequency transfer of nodulating ability between strains and species of Rhizobium. Nature 276, 634-636.

Kondorosi, E., Gyuris, J., Schmidt, J., John, M., Duda, E., Hoffmann, B., Schell, J. \& Kondorosi, A. (1989). Positive and negative control of nod gene expression in Rbizobium meliloti is required for optimal nodulation. EMBO J 8, 1331-1340.

Lamb, J. W., Hombrecher, G. \& Johnston, A. W. B. (1982). Plasmiddetermined nodulation and nitrogen-fixation abilities in Rbizobium phaseoli. Mol \& Gen Genet 186, 449-452.

Lamb, J. W., Downie, J. A. \& Johnston, A. W. B. (1985). Cloning of the nodulation (nod) genes of Rhizobium phaseoli and their homology to R. leguminosarum nod DNA. Gene 34, 235-241.

Maniatis, T., Fritsch, E. F. \& Sambrook, J. (1982). Molecular Cloning: a Laboratory Manual. Cold Spring Harbor, NY: Cold Spring Harbor Laboratory.

Poole, P. S., Franklin, M., Glenn, A. R. \& Dilworth, M. J. (1985). The transport of L-glutamate by Rhizobium leguminosarum involves a common amino acid carrier. J Gen Microbiol 131, 1441-1448. 
Recourt, K., Schripsema, J., Kijne, J. W., van Brussel, A. A. N. \& Lugtenberg, B. J. J. (1991). Inoculation of Vicia sativa subsp nigra roots with Rhizobium leguminosarum biovar viciae results in release of nod gene activating flavonoids and chalcones. Plant Mol Biol 16, 841-852.

Reznikoff, W. S. (1993). The Tn 5 transposon. Annu Rev Microbiol 47, 945-963.

Ronson, C. W. \& Astwood, P. M. (1985). Genes involved in the carbon metabolism of bacteroids. In Nitrogen Fixation Research Progress, pp. 201-207. Edited by H. J. Evans, P. J. Bottomley \& W. E. Newton. Dordrecht: Martinus Nijhoff.

Ronson, C. W., Lyttleton, P. \& Robertson, J. G. (1981). $\mathrm{C}_{4}$ dicarboxylate transport mutants in Rhizobium trifolii form ineffective nodules on Trifolium repens. Proc Natl Acad Sci US A 78, 4284-4288.

Ronson, C. W., Astwood, P. M. \& Downie, J. A. (1984). Molecular cloning and genetic organization of $\mathrm{C}_{4}$-dicarboxylate transport genes from Rhizobium leguminosarum. J Bacteriol 160, 903-909.

Ronson, C. W., Astwood, P. M., Nixon, B. T. \& Ausubel, F. M. (1987a). Deduced products of $C_{4}$-dicarboxylate transport regulatory genes of $\mathrm{R}$ bizobium leguminosarum are homologous to nitrogen regulatory products. Nucleic Acids Res 15, 7921-7934.

Ronson, C. W., Nixon, B. T., Albright, L. M. \& Ausubel, F. M. (1987b). Rbizobium meliloti ntr $A(r p o N)$ gene is required for diverse metabolic functions. J Bacteriol 169, 2424-2431.

Rossen, L., Shearman, C. A., Johnston, A. W. B. \& Downie, J. A. (1985). The nodD gene of Rbizobium leguminosarum is autoregulatory and in the presence of plant exudate induces the nod $A B C$ genes. EMBO J 4, 3369-3373.

Ruvkun, G. B. \& Ausubel, F. M. (1981). A general method for sitedirected mutagenesis in prokaryotes. Nature 289, 85-88.

Sanjuan, J., Grob, P., Gobttfert, M., Hennecke, H. \& Stacey, G.
(1994). NodW is essential for full expression of the common nodulation genes in Bradyrbizobium japonicum. Mol Plant-Microbe Interact 7, 364-369.

Schlaman, H. R. M., Horvath, B., Vijgenboom, E., Okker, R. J. H. \& Lugtenberg, B. J. J. (1991). Suppression of nodulation gene expression in bacteroids of Rhizobium leguminosarum biovar viciae. $J$ Bacteriol 173, 4277-4287.

Schlaman, H. R. M., Okker, R. J. H. \& Lugtenberg, B. J. J. (1992). Regulation of nodulation gene expression by NodD in thizobia. $J$ Bacteriol 174, 5177-5182.

Simon, R., Quandt, J. \& Klipp, W. (1989). New derivatives of transposon $\operatorname{Tn} 5$ suitable for mobilization of replicons, generation of operon fusions and induction of genes in Gram-negative bacteria. Gene 80, 161-169.

Spaink, H. P., Wijffelman, C. A., Pees, E., Okker, R. J. H. \& Lugtenberg, B. J. J. (1987). Rbizobium nodulation gene nodD is a determinant of host specificity. Nature 328, 337-339.

Spaink, H., Wijffelman, C. A., Okker, R. J. H. \& Lugtenberg, B. J. J. (1989). Localization of functional regions of the Rhizobium nodD product using hybrid nodD genes. Plant Mol Biol 12, 59-73.

Surin, B. P., Watson, J. M., Hamilton, W. D. O., Economou, A. \& Downie, J. A. (1990). Molecular characterization of the nodulation gene nodT from two biovars of Rbizobium leguminosarum. Mol Microbiol 4, 245-252.

Watson, R. J., Rastogi, V. K. \& Chan, Y.-K. (1993). Aspartate transport in Rbizobium meliloti. J Gen Microbiol 139, 1315-1323.

Yarosh, O. K., Charles, T. C. \& Finan, T. M. (1989). Analysis of $C_{4}$ dicarboxylate transport genes in Rbizobium meliloti. Mol Microbiol 3, 813-823.

Received 15 September 1994; accepted 5 October 1994. 